\title{
The Paradigm of the Professional Development of a Specialist in the Field of Physical Rehabilitation in according with the Formation of Professionally Significant Experience of a Specialist
}

\section{Парадигма професійного становлення фахівця з фізичної реабілітації з огляду на формування професійно значущого досвіду спеціаліста}

\author{
Liudmyla Prymachok \\ Ph.D. in Pedagogy, Assistant Professor, Scientific Institute \\ of Public Health of National University of Water Management and \\ Nature Usage, Rivne (Ukraine) \\ ORCID ID: https://orcid.org/0000-0002-6591-5223 \\ Researcher ID: F-3874-2019 \\ E-mail: primachok73@ukr.net

\section{Людмила Примачок} \\ Кандидат педагогічних наук, доцент, Навчально-науковий \\ інститут охорони здоров'я Національного університету водного \\ господарства та природокористування, м. Рівне (Україна)
}

\section{ABSTRACT}

The aim of the research is to analyze the problem of experience in a paradigm of psychology, to outline psychological components of professionally significant experience in general, to identify the components of professionally significant experience of a specialist in the field of physical rehabilitation, taking into account the peculiarities of his / her professional activity.

Address for correspondence, e-mail: kpnu_lab_ps@ukr.net Copyright: (C) Prymachok Liudmyla

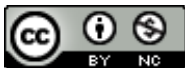

(C) Prymachok Liudmyla

DOI (article): https://doi.org/10.32626/2227-6246.2020-47.179-205 
DOI: https://doi.org/10.32626/2227-6246.2020-47

2020. випуск 47

Methods of the research. The following theoretical methods of the research were used to solve the tasks formulated in the article: a categorical method, structural and functional methods, the methods of the analysis, systematization, modeling, generalization.

The results of the research. Professionally meaningful experience will have valuable, reflexive, communicative and operational characteristics. It is this set of parameters of experience that ensures the independence of the individual, his / her creative or reflexive activity. Professionally significant experience is also gained in situations of involuntary activity, immediate (or insight) responses, the situations which are full of automatisms, adaptive or constructive actions. It is emphasized that both personally significant and professionally meaningful experience is not only a scientific problem, but also a matter of life formation of personality, a problem of constructing his / her own image of the world. A professionally meaningful experience allows the subject to propose a model or a plan of professional activity, to present the scale of life ideas, which will allow the person to realize his / her own place at each more or less important moments of life, to build a bifurcation space of personal and professional growth.

The activity of the individual, his / her position according to professionally meaningful society is not only and not so much presented that he / she thus "contributes» to something in common, integral and social, but that he / she is able to create without direct coordination with all representatives of the society, his / her own system of ways of professional interaction with people, a kind of social-interpretation professionally oriented complex. It is stated that the approach to the problem of professionally meaningful experience is especially important for the field of physical rehabilitation, since the specialist has to show exceptional skills to perform professional activity in a system not of the abstract paradigm, but according to his / her own system of world.

Conclusions. The components of professionally significant experience of a specialist in a field of physical rehabilitation are defined to include: 1) valuable experience; 2) the experience of reflecting his / her own professional activity; 3) operational experience. It is stated that the valuable experience fulfills the following functions: a developmental one, a differential function, the integrative one, semantic and self-determining functions, and a function of conservation. The functions of the component "experience of reflecting his / her own professional activity» are: subjectively updated function, a preventive one, the interpretive and the adaptive functions, also the function of adjustment. Functions of operational experience include: a consultative function, a cognitive one, communicative and (C) Prymachok Liudmyla

DOI (article): https://doi.org/10.32626/2227-6246.2020-47.179-205 
perceptive functions, a psychotherapeutic and a nominative ones, the function of stating the purpose and coding the information.

Key words: professionally significant experience, valuable experience, the experience of reflecting his / her own professional activity, operational experience, functions of professionally significant experience.

\section{Вступ}

Значущим для професійного становлення фахівця будьякої сфери діяльності, в тому числі - 3 фізичної реабілітації, є професійний досвід спеціаліста. Характерною особливістю індивідуального досвіду особистості, вважає О. Лактіонов, є його універсальність відносно різнорівневих аспектів психіки людини. Індивідуальний досвід рівною мірою детермінований «матеріальними» (пам'ять, інші пізнавальні процеси), «субстанційними» (особистість, духовність) і соціальними (індивід - соціум) рушійними силами людського буття (Лактіонов, 2000: 62).

Проте проблема структури професійно значущого досвіду в психологічній літературі до цих пір залишається недостатньо розробленою. Як правило, вчені та науковці досить по-різному в парадигмальному плані розглядають структурні складові досвіду. Тому, незважаючи на те, що багато років проблема досвіду цікавила науковців і вчених, термін «досвід», як правило, залишається багатозначним за своїм змістом і смисловими характеристиками. Стосовно клієнта досвід (experience) розуміється як «проживання» певної ситуації, як часткове або повне усвідомлення себе, як особливий емоційно-рефлексивний стан, i, нарешті, - як сукупність знань про самого себе, своє «Я». Останнє значною мірою детермінується сферами професійної активності особистості. У будь-якому випадку професійний досвід $€$ певною фреймовою структурою, що уособлює безперервний розвиток людини і фасилітується своєю власною волею.

Тому, зважаючи на актуальність порушеної проблеми, мета нашої статті - проаналізувати проблему досвіду в пси-

(C) Prymachok Liudmyla DOI (article): https://doi.org/10.32626/2227-6246.2020-47.179-205 
хологічній царині, окреслити психологічні складові професійно значущого досвіду загалом і виокремити компоненти професійно значущого досвіду фахівця з фізичної реабілітації, зважаючи на особливості професійної діяльності спеціаліста цієї сфери діяльності.

\section{Завдання статті}

1. Проаналізувати наукову літературу з проблеми професійно значущого досвіду, зокрема з урахуванням генезису життєвого шляху й індивідуального досвіду особистості.

2. Окреслити категоріальний простір професійно значущого досвіду, описати особливості набуття суб'єктом професійно значущого досвіду з огляду на процеси професійного становлення та життєдіяльність індивіда.

3. Запропонувати власну концепцію професійно значущого досвіду фахівця з фізичної реабілітації з урахуванням особливостей професійної діяльності даного спеціаліста (описати структурні складові досвіду та визначити функції, які виконують ці компоненти).

\section{Методи дослідження}

Для розв'язання поставлених у роботі завдань використовувалися такі теоретичні методи дослідження: категоріальний, структурно-функціональний аналіз, систематизація, моделювання, узагальнення.

\section{Результати та дискусії}

Поняття досвіду досить широко вживається в гуманістичній психології і, зокрема, в теорії К. Роджерса (Роджерс, 1990). Так, K. Роджерс (Rogers, 1983) неодноразово наголошує на особливій пріоритетності досвіду в житті людини: «Я думаю, що кожна людина має вірити своєму життєвому досвіду, який, я підозрюю, є набагато розумнішим, ніж мій інтелект. Звичайно, мій досвід може помилятися, але, сподіваюся, меншою мірою, ніж інтелект, окремо взятий» (Роджерс, (C) Prymachok Liudmyla

DOI (article): https://doi.org/10.32626/2227-6246.2020-47.179-205 
1996: 64). Базову проблему, яку була змушена поставити перед собою гуманістична психологія (Роджерс, 1996: 63), щодо «екологічної валідності» психотерапевтичних процедур, - К. Роджерс (Роджерс, 1996) також фіксує на аксіології суб’єктивного досвіду: «Досвід для мене є найвищим авторитетом. Характеристика валідності - мій власний досвід. Ані думки інших, ані мої власні думки не є важливими настільки, як мій власний досвід. Саме до досвіду я повинен знову i знову повертатися, щоб, урешті-решт, наблизитися до розуміння істини, як це і відбувається у процесі мого власного розвитку» (Роджерс, 1996: 124).

У своїх працях К. Роджерс (Роджерс, 1996: 64) неодноразово детально описує стадіальність професійно значущого досвіду особистості: «Як тільки клієнт починає рухатися до того, щоб бути здатним приймати свій власний професійно значущий досвід, він також намагається рухатися до прийняття досвіду інших людей. Він цінує і приймає свій досвід і досвід інших такими, якими вони є насправді" (Роджерс, 1996: 223-224). За умов цього процесу, як правило, відбуваються доволі закономірні зрушення у структурі особистості. Клієнт краще уявляє собі, чого він бажає, які його взаємостосунки 3 іншими. Ситуація «тут-і-тепер» переживається ним не як повторення добре відомого, пережитого, а як зовсім нове. Набуті особистісні скрипти, конструкти, фрейми, стереотипи, настановлення набувають рухливості, завдяки чому клієнт отримує неабияку можливість перевірити їх відповідність новому професійно значущому досвіду.

Отже, К. Роджерс одним із перших описав процес самоперетворення особистості з огляду на розкриття людиною своїх найкращих особистісних якостей і властивостей. Наприклад, говорячи щодо суб'єктності, ми набуваємо особистісно значущого досвіду як атрибуту суб'єкта (на цьому неодноразово наголошувалося в останніх роботах із культурно-історичної парадигми). Особливо часто - з огляду на аналіз випадків, пов'язаних зі специфікою повсякденного (C) Prymachok Liudmyla DOI (article): https://doi.org/10.32626/2227-6246.2020-47.179-205 
життя, навчанням дітей, урахуванням психологічних чинників і детермінант їх особистісного розвитку тощо (Rogers, 1983).

Ми вважаємо, що професійно значущий досвід є досвідом пережитої особистістю поведінки, діяльності, у процесі виконання якої сама людина може собі дати звіт щодо власне своїх можливостей. Професійно значущий досвід створює позитивні передумови для організації власних дій і власного ставлення до об’єктів і суб'єктів професійної діяльності. Своєю чергою, у цьому ставленні фіксуються найбільшою мірою значущі для людини цінності, створюється певна ієрархія уявлень, які вона здатна цілковито усвідомити, зрозуміти, що саме вона має зробити для вдосконалення своєї професійної діяльності, набуття професійної майстерності тощо.

Так, професійно значущий досвід, на наше стійке переконання, матиме ціннісні, рефлексивні, комунікативні й операційні характеристики. Саме така сукупність параметрів досвіду забезпечує самостійність індивіда, його ціле-творчу або рефлексивну діяльність. Професійно значущий досвід також набувається у ситуаціях мимовільної активності, негайного (або інсайтного) реагування, автоматизмів, адаптивних або конструктивних дій тощо. При цьому слід наголосити, що й особистісно значущий, і професійно значущий досвід $\epsilon$ не лише науковою проблемою, але питанням життєтворення особистості, проблемою побудови свого власного образу світу. Професійно значущий досвід дає змогу суб'єктові змоделювати план виконання професійної діяльності, презентувати масштаб життєвих уявлень, що дозволятиме особистості в кожний більш-менш важливий момент життєвого шляху усвідомити власне своє місце, побудувати біфуркаційний простір особистісного та професійного зростання тощо.

У науковій літературі (Рикер, 2002; Ролло, 2001) неодноразово наголошується, що професійно значущий досвід пов'язаний не лише із самою по собі професійною діяль(c) Prymachok Liudmyla

DOI (article): https://doi.org/10.32626/2227-6246.2020-47.179-205 
ністю, а і з життєдіяльністю суб'єкта. Отже, проаналізуємо деякі важливі змістові аспекти порушеної проблеми.

Коли мова йде про аналіз певного ідеального предмета як перетвореної форми, деякі труднощі становить вибір найближчого інтервалу переходу змісту до парадигми форми. За умов зростання відстані між змістом і формою значно актуалізується й опосередкування окреслених процесів. У таких випадках велика кількість опосередкованих фреймів робить форму більшою мірою «порожньою» порівняно зі своїм першоджерелом. Отже, завдання нашого дослідження полягає у фіксації та можливому зближенні (наповненні) такої відстані.

У вітчизняній психології є класичний приклад того, коли життєдіяльність була обрана в якості родового поняття. Відомо, що в основу вивчення мимовільного запам'ятовування А. Зинченко поклав дослідницьку парадигму «життєдіяльність - пам'ять» (Зинченко, 1984: 204-206). Але і в іiі межах було зафіксовано досить велику відстань між головними поняттями, що закономірно дозволяло розмістити між ними поняття «особистісно значущий досвід». Таку теоретичну операцію успішно виконав Л. Доблаєв (Доблаев, 1973: 10-11). Надалі це дало змогу вже у межах парадигми «досвід - пам'ять» виявити цілу низку нових характеристик пам'яті (Калмыкова \& Мергенталер, 1998).

Говорячи про «кількість опосередкувань», ми розуміємо, що такий кількісний метод аналізу вельми спрощує реальну картину, яка має місце, перш за все, завдяки якісним змінам у разі переходу свідомості особистості з одного рівня опосередкування на інший.

У плані розвитку власне парадигмальних уявлень щодо категоріального простору професійно значущого досвіду, корисно поставити запитання, як саме ми сприймаємо процес життєдіяльності. Добре відомим є те, що більш парадигмальною, ніж життєдіяльність, категорією, яка має онтологічний статус, є біологічна активність, тобто - життя на

(C) Prymachok Liudmyla

DOI (article): https://doi.org/10.32626/2227-6246.2020-47.179-205 
Землі (Выготский, 1983). У такому сприйнятті життєдіяльності досить очевидним є фактична неповнота такого способу категоріального розширення простору, як опосередкування рівня біологічної активності відносно рівня життєдіяльності. Деякі вчені, зокрема І. Ващенко та Л. Онуфрієва (Ващенко \& Онуфрієва, 2018), Н. Михальчук і Н. Хупавцева (Михальчук \& Хупавцева, 2011), вважають, що саме таке тлумачення життєдіяльності надає їй статусу духовності. Так, І. Ващенко та Л. Онуфрієва зазначають: «Однак розвиток особистості відбувається впродовж усього життя. Активне становлення особистості починається 3 дитинства і продовжується до зрілого віку. Тому на різних вікових етапах на формування копінг-стратегій впливатимуть різні особистісні чинники. Імовірно, починаючи з юнацького віку, коли сформовані теоретичне мислення, ціннісно-смислова сфера й ідентичність особистості, структури долаючої поведінки набувають більш сталого характеру і підпадають під вплив певних, уже сформованих особистісних властивостей людини. Особистість завжди потенційно є активною і вирішує, які характеристики й об'єктивні умови ситуації зробити власними ресурсами» (Ващенко \& Онуфрієва, 2018: 234-235). До таких характеристик, без сумніву, відноситься й категорія професійно значущого досвіду. Саме в цьому контексті Н. Михальчук і Н. Хупавцева постулюють життєдіяльність як трансцендентну категорію (Михальчук \& Хупавцева, 2011). Отже, професійно значущий досвід переходить, по суті, до іншого рівноправного джерела життєдіяльності, яким є власне їі перетворена форма, потрібна людині, по-перше, для досягнення мети професійної діяльності, а, по-друге, з ціллю збагачення та перетворення себе самої на духовного суб'єкта, який здатен цілком самостійно реалізувати себе у професійній площині.

Тому можна зробити висновок, що сенс окресленої вище проблеми життєдіяльності та набуття професійно значущого досвіду виявляється лише за умов зниження рівня категорі(c) Prymachok Liudmyla

DOI (article): https://doi.org/10.32626/2227-6246.2020-47.179-205 
альності професійного простору та його переходу на рівень «чуттєве - раціональне». Отже, науково обгрунтований висновок полягає в тому, що центральною категорією в плані аналізу природи професійно значущого досвіду людини дійсно є життєдіяльність, яка вже не вступає в протиріччя 3 моделлю «чуттєве - раціональне», а актуалізує ці поняття 3 метою формування свого професійного категоріального простору. Іншими словами, між набуттям суб'єктом професійно значущого досвіду та процесом професійного становлення центральною є опосередкувальна ланка - життєдіяльність індивіда.

Професійно значущий досвід не є абсолютною, тим більше - сталою характеристикою суб'єкта. I справа тут не в тому, що професійно значущий досвід не може залишатися незмінним упродовж усього життя індивіда. Релятивність професійно значущого досвіду постає зрозумілою з діалектики його взаємодії з процесом життєдіяльності суб’єкта. Розвиток особистості кожної людини не починається лише з початком набуття професійно значущого досвіду і не закінчується на ньому. Професійно значущий досвід постає необхідним як змістове наповнення безперервного існування індивіда у просторі «тут-і-тепер». I для дитини, і для дорослої людини він є досить відносним, тому що у просторі життєдіяльності в різноманітних ставленнях щодо професійно значущого досвіду актуалізується смислоутворювальний план життя загалом, який визначається, крім усього іншого, нормами соціальної етики й особистісної моралі. Лише усвідомлення зрілою особистістю свого професійно значущого досвіду стає реальною підставою для «виходу» фахівцем за його межі. Саме в момент «виходу» особистості за межі професійно значущого досвіду («своєрідний розрив досвіду») останній починає виявлятися у своїй канонічній для конкретного індивіда формі.

Уявлення щодо професійно значущого досвіду як системи, котра постійно розвивається, дає змогу відобразити його (C) Prymachok Liudmyla DOI (article): https://doi.org/10.32626/2227-6246.2020-47.179-205 
як системо-діахронічну, тобто ту, що розгортається в часі, структуру. Далі, якщо ми приймаємо за істину те, що формувальною основою професійно значущого досвіду є життєдіяльність індивіда з різними випереджаючими одна одну фазами розвитку, то можна припустити, що кожна людина упродовж своєї професійної діяльності оволодіває не просто одним «єдиним» досвідом, а різними його видами. Іншими словами, професійно значущий досвід є завжди гетерогеннил. За одними характеристиками ми можемо виокремити особистісний і соціальний (екзистенційна гетерогенність), за іншими - старий і новий (історична гетерогенність) підвиди досвіду особистості. При цьому головним є те, що ці види досвіду, незважаючи на всю свою автономність і навіть можливу контраваріативність (розвиток у протилежних напрямках), здатні співіснувати у свідомості індивіда не тільки не гальмуючи його особистісне становлення, але й стимулюючи останне.

Взаємовідносини життєдіяльності й професійно значущого досвіду як відношення змісту і його перетвореної (завдяки виконанню професійної діяльності) форми є найважливішими, порівняно з тими психологічними характеристиками, у яких за допомогою змісту можуть бути безпосередньо відображені зовнішня або внутрішня форми презентації професійно значущого досвіду. Структурні компоненти професійно значущого досвіду великою мірою маскують своє походження, залишаючи можливість припускати наявність низки опосередковувальних ланок, зафіксованих у парадигмі професійно значущого досвіду в досить компресованому вигляді.

Із нашої точки зору однорівневою для поняття професійно значущого досвіду є категорія «життєвий шлях». Теоретичні основи вивчення життєвого шляху у вітчизняній психології було закладено Б. Ананьєвим (Ананьев, 2007), С. Рубінштейном (Рубинштейн, 1989), Т. Титаренко (Титаренко, 1995). Поняття «життєвий шлях», «індивідуальний (c) Prymachok Liudmyla

DOI (article): https://doi.org/10.32626/2227-6246.2020-47.179-205 
шлях життя", як і поняття «особистісно значущий досвід», «досвід індивіда», «індивідуальний досвід особистості» та «професійно значущий досвід», представляють собою окремі семантичні кола. Разом із тим, вони відображають дві характеристики поняття «життєдіяльність», адже постають як генетично взаємопов'язані й рівноправні за своїм значенням.

Якщо індивідуальний досвід розуміється вченими як системне функціональне ціле, що відображає життєдіяльність кожної окремої особистості, то природно припустити, що однорівневою з цією категорією за масштабом буде життєвий шлях. Останній, як і індивідуальний (або особистісно значущий) досвід, може розглядатися як певна форма життєдіяльності та як їі результат. Водночас життєвий шлях, набуваючи статусу передумови, детермінанти, завдяки усвідомленню індивідом психологічного часу свого життя великою мірою впливає на характер життєдіяльності кожного фахівця. Цей процес є досить складним як за своєю структурою, так і за функціональними характеристиками, і не відбувається автоматично; проблема полягає в природі самого феномену психологічного часу. Зокрема, Т. Титаренко зазначає: «Плин психологічного часу є досить нерівномірним, нелінійним, різноспрямованим. Розуміння його впливу на всі прояви життєдіяльності зростає із формуванням самосвідомості особистості людини, яка, знаходячись у конкретній часовій перспективі, актуалізує свої можливості упродовж досить обмеженого періоду часу, який дається нам у цьому житті» (Титаренко, 1995: 319).

Отже, слід проаналізувати, як саме можуть бути пов'язані ці дві сторони життєдіяльності. Зокрема, О. Лактіонов виходить із гіпотези щодо їх структурно-динамічного поліморфізму, який реалізується в багатозначних зв'язках виокремлення «шляху» і «досвіду». Відносно певної конкретної людини (життєдіяльність) шлях і досвід постають як категорії, що доповнюють одна одну. Досвід розуміється не як особливі якості людини, які протистоять життєвому

(C) Prymachok Liudmyla

DOI (article): https://doi.org/10.32626/2227-6246.2020-47.179-205 
шляху особистості, а як певна структурована констеляція тих самих якостей, які за інших умов стають атрибутивними характеристиками життєвого шляху особистості (Лактіонов, 2000).

Так само, як і індивідуальний досвід, життєвий шлях людини безпосередньо пов'язаний із повсякденністю (Томе, 1996). Як і досвід, життєвий шлях має якість універсальності, й завдяки цьому постає атрибутивною характеристикою кожної людини.

Тривалий час життєвий шлях розкривався в різних більш-менш розгорнутих життєписах, коли письменники певною мірою могли конкурувати з психологами. При цьому завжди малося на увазі, що все, що відбувається на життєвому шляху відомої особистості, як правило, не піддається вичерпному опису або вимірюванню. Лише в останні чотири десятиліття, коли була усвідомлена необхідність побудови власне психологічного предмета дослідження, життєвий шлях досяг рівня сконструйованого поняття, яке можна виміряти. Отже, основна функція життєвого шляху стосовно індивідуального досвіду полягає в установленні для останнього необхідної просторово-часової координатної сітки. Навпаки, якщо ми бажаємо здійснити змістове вимірювання деяких психологічних одиниць життєвого шляху, нам відкривається не що інше, як досвід людини в даному пункті вимірювання, тобто досвід, експлікований «тут і зараз».

У вигляді форми життєдіяльності Л. Сохань, В. Тихонович, Є. Головаха виокремлюють категорію життєздійснення, що постає своєрідною опосередковувальною ланкою між досвідом особистості та життєвим шляхом: «У парадигмі соціально-психологічного механізму життєздійснення особливе значення має життєва подія і життєвий досвід. На їхній основі формуються певні етапи життєвого шляху, відбувається актуалізація життєвих цілей, розгортається достатньо об'єктивна картина життя» (Сохань, Тихонович \& Головаха, 1989: 7).

(C) Prymachok Liudmyla

DOI (article): https://doi.org/10.32626/2227-6246.2020-47.179-205 
Визначити характеристики життєвого шляху окремої людини означає з урахуванням парадигми просторово- (біологічне $\rightarrow$ психологічне $\longleftarrow$ соціально-історичне) часової (минуле $\rightarrow$ теперішнє $\rightarrow$ майбутнє) координації розкрити особливості життєвих дій і вчинків фахівця. Тим самим, завдяки аналізу життєвого шляху можна змоделювати психобіографію індивідуального досвіду особистості.

Ученими також наголошується, що існують і такі парадигми психологічних вимірів, де життєвий шлях та індивідуальний досвід безпосередньо перетинаються. До них належать спогади про минуле як феномен усвідомлення часу життя i, з іншого боку, як феномен експлікації набутого досвіду, який зберігається у пам'яті людини.

Таку ж подібність можна виявити на шкалі «майбутнього». К. Левін вважає, що життєвий шлях завжди переживається як незавершений, тому що нікому не відомо, коли і як він закінчиться. На відміну від цього, особистісно значущий (життєвий) досвід усвідомлюється як набутий, накопичений, сталий, завершений. Але це - лише часткові уявлення щодо моменту переживання особистісно значущого досвіду. Залежно від позиції особистості (наприклад, відповідальності, інтернальності, творчості тощо) суб'єкт досвіду, орієнтуючись на майбутні завдання і задачі, зіставляючи власні досягнення з можливостями інших людей, виходить за межі набутого особистісно та професійно значущого досвіду, переживаючи його як незавершений, недосконалий, такий, що потребує постійної праці над собою, своєю особистістю (Lewin, 1989: 44, 868-896).

Якщо проаналізувати генезис життєвого шляху й індивідуального досвіду особистості, то цілком зрозумілою постає їх слислова зворотність. Ми вважаємо, що життєвий шлях суб'єкта значною мірою детермінується змістом його особистісно значущого досвіду, а індивідуальний досвід людини формується відповідно до специфіки їі життєвого шляху. Досліджуючи ці поняття, Т. Титаренко пише: «Особистість (C) Prymachok Liudmyla DOI (article): https://doi.org/10.32626/2227-6246.2020-47.179-205 
DOI: https://doi.org/10.32626/2227-6246.2020-47

у їі генезі слід розглядати з урахуванням їі світу, мікрокосму, який вона самостійно будує, створює, вдосконалює. Мається на увазі життєвий досвід як результат розгортання ззовні індивідуальних цінностей і смислів, і структурування щодо них зовнішньої дійсності» (Титаренко, 1995: 328).

У певному сенсі проміжною характеристикою, котра наголошує на генетичній спорідненості життєвого шляху й особистісно значущого досвіду, є внутрішня картина життєвого шляху як своєрідний цілісний образ людського буття (Крупа, 2015). Деякі вчені, зокрема Ю. Смельянов, вважають, що внутрішня картина життєвого шляху вміщує до свого змісту деякі базові компоненти: 1) соматичний ставлення до свого тіла; 2) суб'єктний - ставлення до себе як до особистості, ставлення до своєї поведінки, діяльності, що фасилітує формування думок, бажань, а також захисних механізмів психіки тощо; 3) ситуативний - ставлення до ситуацій, у які людина виявляється включеною упродовж свого життєвого шляху (Емельянов, 1985: 3-4).

Отже, внутрішня картина життєвого шляху є відображенням його змістових інтенцій, хоча останній сам по собі внутрішній цілісний «образ світу» (Леонтьев, 1983) не формує. Водночас внутрішня картина світу $є$ рефлексивною характеристикою індивідуального досвіду, завдяки якому внаслідок виконання професійної діяльності людина здатна формувати і коригувати власний життєвий шлях.

Досить оригінальною є точка зору О. Лактіонова, який вважає, що психологічна природа професійно значущого досвіду буде цілісною, якщо не брати до уваги наявність двох критичних моментів, універсальних для життєдіяльності індивіда, його життєвого шляху на початку і наприкінці життя людини, які вчений відповідно називає «нульдосвід» і «вільний досвід» (Лактіонов, 2000).

Отже, досвід у своїй початковій формі вже існує як такий у момент народження дитини. Досвід має свої власні характерні особливості, які не залежать від життєдіяльності (C) Prymachok Liudmyla

DOI (article): https://doi.org/10.32626/2227-6246.2020-47.179-205 
індивіда, зберігає в собі історію своїх прабатьків і, головне, спочатку існує у вигляді чистої форми нуль-досвіду - тієї якісної визначеності, яка буде головною для досвіду впродовж усього життя індивіда. К. Юнг також наголошує, що трансформація досвіду з чистої форми у перетворену відбудеться пізніше, коли досвід, підкорений життєдіяльності, стане «свідомим досвідом». Коли йдеться про інверсію досвіду як власний здобуток, К. Юнг має на увазі факт експлікації знань і традицій предків у статус особистісної автентичності суб'єкта, яка згодом, за умов роботи над собою як професіоналом, фасилітуватиме становлення професійної надійності особистості (Юнг, 1998).

Так само після закінчення життя певного представника людського роду його досвід перестає бути ніби його «власністю», втрачає якість перетвореної форми життєдіяльності, але есплікується у чисту форму «вільного досвіду», який, разом із тим, повною мірою залежить від нових поколінь. У науковій літературі зазначалося, що серед інших форм досвіду саме «вільний досвід» є найприроднішим «ідеальним» об'єктом для становлення професійної майстерності суб'єкта. Уявлення щодо інверсії професійно значущого досвіду дає нам підстави зробити висновок, що моменти початку i кінця життя не є психологічно порожніми. 3 цього висновку стає зрозуміло, що навіть якщо життєдіяльність індивіда виявилася змістовно більш «насиченішою» за його досвід, то, при цьому, досвід індивіда все ж таки буде «ширшим» за життєдіяльність за часом буття (парадигма досвіду матиме набагато ширші межі). Тому, якщо говорити про спадкоємність поколінь, зв'язку сучасного і «минулих» життів, життєвих планів тощо, то механізмол такої наступності постає професійно значущий досвід: змістовне пов'язується через свою форму і з професійною автентичністю, і з професійною надійністю, і з унікальністю особистості тощо.

Із метою побудови моделі професійно значущого досвіду фахівця з фізичної реабілітації окреслимо особливості про-

(C) Prymachok Liudmyla DOI (article): https://doi.org/10.32626/2227-6246.2020-47.179-205 
DOI: https://doi.org/10.32626/2227-6246.2020-47

фесійної діяльності цього спеціаліста. Головна мета професійної діяльності реабілітолога - збереження життя людини і покращення його якості шляхом надання ургентної, планової і превентивної допомоги. Фахівець із фізичної реабілітації зобов'язаний постійно бути готовий надати ургентну медичну допомогу будь-якій людині незалежно від статі, вікової та національної приналежності пацієнта, його соціального статусу, релігійних і політичних переконань, а також інших немедичних чинників, включаючи матеріальне становище. Пропозиція безоплатної допомоги незаможній особистості є етичною і виправданою. Фахівець із фізичної реабілітації має всіма легальними способами сприяти справі охорони здоров'я населення, в тому числі - здійснюючи просвітницьку діяльність із питань медицини, гігієни, екології та культури спілкування тощо.

В етичному кодексі лікаря мова йде про те, що фахівець із фізичної реабілітації (так само, як і лікар) має поважати честь і гідність пацієнта. Нетактовне і негуманне ставлення до пацієнта, приниження його людської гідності, а також будь-які прояви зверхності або надання переваги будь-якому пацієнту, чи виявлення неприязні зі сторони фахівця 3 фізичної реабілітації є недопустимими. Спеціаліст повинен надавати медичну допомогу в умовах мінімально можливого утиску свободи пацієнта, а у деяких випадках, які за медичними показами потребують встановлення спеціального контролю за поведінкою пацієнта, - суворо обмежувати медичні втручання межами суворої необхідності.

Професіоналізм фахівця з фізичної реабілітації виявляється у професійній діяльності, сутність якої складають дії (спілкування, діалог, взаємодія) на основі ціннісних настановлень і морально-етичних орієнтацій, що визначають універсальні права й окреслюють основні свободи людини, які і є метою означеної діяльності. Професія фахівця з фізичної реабілітації нерідко висуває до особистості спеціаліста вимоги, пов'язані з емоційними перевантаженнями, части(c) Prymachok Liudmyla

DOI (article): https://doi.org/10.32626/2227-6246.2020-47.179-205 
ми стресовими ситуаціями, з дефіцитом часу, необхідністю приймати рішення у випадку доволі обмеженого обсягу інформації, з високою частотою й інтенсивністю міжособистісних взаємостосунків. 3 огляду на специфіку професійної діяльності фахівця з фізичної реабілітації слід зазначити, що спеціаліст нерідко стикається зі співчуттям, болем, патологічними і психологічними змінами особистісної сфери пацієнтів. Професійна діяльність фахівця з фізичної реабілітації - особливий вид діяльності, який характеризується станом постійної патологічної готовності, емоційної залученості до проблем оточуючих, пов'язаних зі станом їх здоров'я, практично в будь-якій ситуації, яка припускає здійснення ефективної міжособистісної взаємодії.

Спеціалістам із високим рівнем сформованості професійної майстерності, професійної компетентності притаманний суб'єктний тип взаємостосунків із пацієнтами, що загалом свідчить про розвиток суб'єктності особистості конкретного фахівця. Зазначимо, що суб'єктний тип взаємостосунків є такою формою взаємодії медперсоналу з пацієнтом, у якій відображаються і враховуються соціальний, соматичний i психічний статус пацієнтів, їх потреби й інтереси, бажання і мотиви, настрої і турбота про здоров'я, а також есплікується право отримувати необхідну допомогу, підтримку та піклування.

Вважаємо, що в професійній діяльності реабілітолога можна виокремити чотири взаємопов'язані блоки: мотиваційно-ціннісний, інтенційно-діяльнісний, рефлексивно-регуляційний, креативно-операціональний. У межах кожного блоку експлікуються ті якості суб’єкта, що відповідають за функціонування і розвиток відповідної сфери особистості фахівця з фізичної реабілітації. Мотиваційно-ціннісний блок уміщує мотиви і цілі професійної діяльності реабілітолога, а також структуру цінностей фахівця. Інтениійно-діяльнісний блок характеризується поєднанням таких структурних складових: здатностей і здібностей реабілітоло-

(C) Prymachok Liudmyla DOI (article): https://doi.org/10.32626/2227-6246.2020-47.179-205 
га до розв'язання професійних завдань і задач; здатності до співпраці, бачення унікальності іншої людини, активності у налагодженні контактів. Рефлексивно-регуляційний блок пов'язаний із професійною рефлексією, критичною оцінкою професійних знань з огляду на особливості реальної професійної діяльності фахівця з фізичної реабілітації. Креативно-операціональний блок містить особистісні якості та можливості професійного розвитку і самовдосконалення.

Отже, до колпонентів професійно значущого досвіду фахівця з фізичної реабілітації ми відносимо:

1) ціннісний досвід;

2) досвід відрефлексування власної професійної діяльності;

3) операціональний досвід.

При цьому иіннісний досвід виконує такі функиії: розвивальну, диференційну, інтегративну, смислову, самовизначальну, функцію збереження. Своєю чергою, функиіяли компонента «досвід відрефлексування власної професійної діяльності» можна вважати: суб'єктно актуалізовану, профілактичну, інтерпретативну, адаптивну та функцію коригування. До функиій операціонального досвіду відносимо: консультативну, пізнавальну, комунікативну, перцептивну, психотерапевтичну, номінативну, функції цілевизначення та кодування тощо.

Модель професійно значущого досвіду фахівця з фізичної реабілітації зображено на рис. 1 .

В індивідуальному просторі професійно значущого досвіду існує певний репертуар стереотипних способів, прийомів, засобів, що дають змогу встановлювати контакт спеціаліста з пацієнтом і здійснювати оптимальну взаємодію навіть за умов, коли, наприклад, емпатія в одного або обох членів діади знижена, або неповною мірою розвинена здатність до узагальнення та раціоналізації, або не збігаються (різняться) ціннісні орієнтації тощо. У таких випадках неабияку роль відіграють професійна надійність, професійна (c) Prymachok Liudmyla

DOI (article): https://doi.org/10.32626/2227-6246.2020-47.179-205 
автентичність і професійна унікальність, адже саме ці якості створюють професійно значущий простір, до якого, як правило, включено базові динамічні структури професійно значущого досвіду, що дає змогу фахівцеві адекватно і відповідально здійснювати професійну взаємодію.

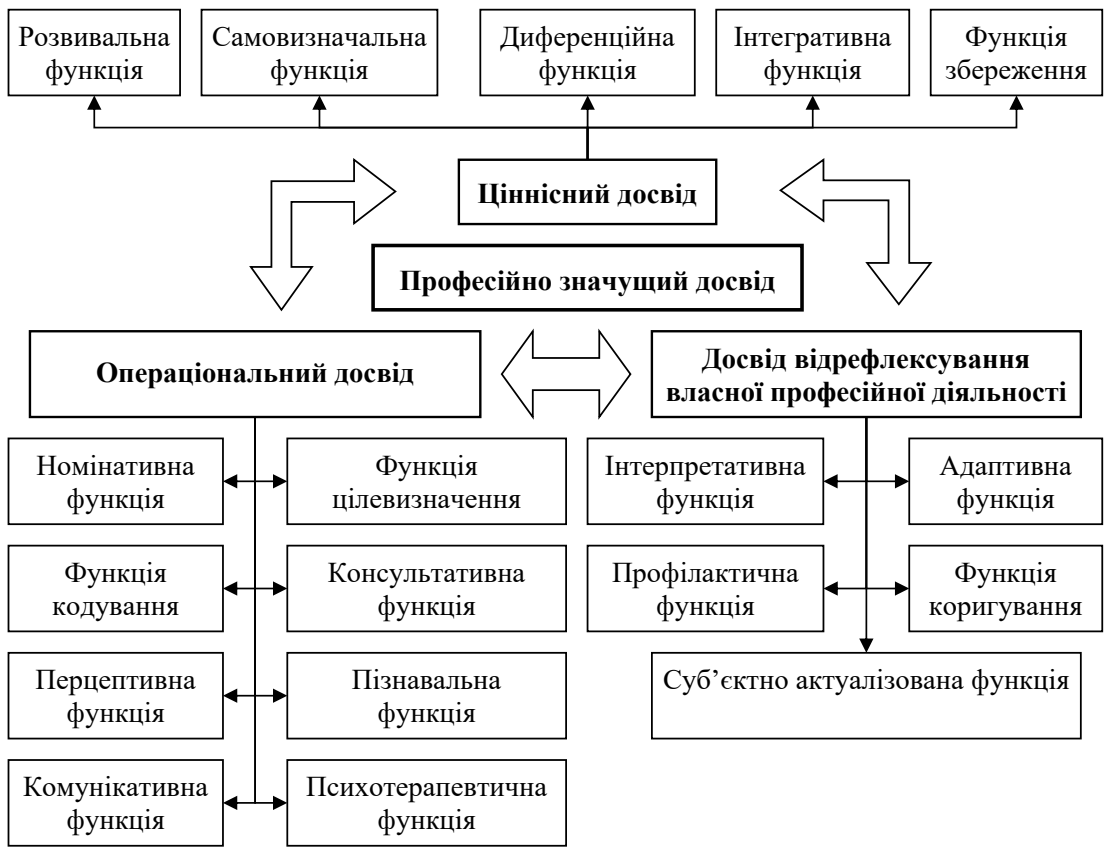

Puc. 1. Функціональний простір професійно значущого досвіду фахівця з фізичної реабілітації

\section{Висновки}

Ми вважаємо, що різні явища суспільного, культурного та професійного життя фахівця формують його особистісно та професійно значущий досвід, що певним чином відображає пріоритетні на даний момент ціннісні орієнтації людей, об’єднаних з огляду на існуючу культурну, етнічну, національну, цивілізаційну основу.

(C) Prymachok Liudmyla

DOI (article): https://doi.org/10.32626/2227-6246.2020-47.179-205 
DOI: https://doi.org/10.32626/2227-6246.2020-47

Так, професійно значущий досвід фахівця з фізичної реабілітації являє собою особливий психологічний інструмент забезпечення професійної діяльності, тому він особливим чином організований, а не існує ніби «паралельно» соціальній активності індивіда. Отже, між соціальною активністю і ïi дериватами - особистісно та професійно значущим досвідом не спостерігаються відносини ізоморфізму.

Активність індивіда, його позиція щодо професійно значущого соціуму виявляється не тільки і не стільки в тому, що він таким чином «робить внесок» у дещо спільне, інтегрально-соціумне, а в тому, що він здатний без безпосереднього узгодження з усіма представниками соціуму створювати власну систему способів професійної взаємодії з людьми, своєрідний соціально-інтерпретаційний професійно спрямований комплекс. Такий підхід до проблеми професійно значущого досвіду $є$ особливо важливим для галузі фізичної реабілітації, адже фахівець повинен виявляти неабиякі вміння виконувати професійну діяльність у системі не абстрактної парадигми, а свого власного, набутого професійно значущого досвіду.

До компонентів професійно значущого досвіду фахівця з фізичної реабілітації ми відносимо: ціннісний досвід; досвід відрефлексування власної професійної діяльності; операціональний досвід. Ми вважаємо, що ціннісний досвід виконує такі функції: розвивальну, диференційну, інтегративну, смислову, самовизначальну, функцію збереження. Функціями компонента «досвід відрефлексування власної професійної діяльності» вважаються: суб’єктно актуалізована, профілактична, інтерпретативна, адаптивна та функція коригування. До функцій операціонального досвіду відносяться: консультативна, пізнавальна, комунікативна, перцептивна, номінативна, психотерапевтична, функції цілевизначення та кодування тощо.

(C) Prymachok Liudmyla

DOI (article): https://doi.org/10.32626/2227-6246.2020-47.179-205 


\section{Література}

Ананьев Б. Г. Избранные психологические труды: в 2 т. Санкт-Петербург : Изд-во СПбГУ, 2007. Т. 1. 287 с.

Ващенко I. В., Онуфрієва Л. А. Концептуальні межі поняття копінг-стратегій особистості у психології. Проблели сучасної психології: Збірник наукових праць Кам'янець-Подільського національного університету ілені І. Огієнка, Інституту психологї ілені Г. С. Костюка НАПН України. Кам'янець-Подільський : Аксіома, 2018. Вип. 41. С. 228-239. DOI 10.32626/2227-6246.201841.228-239.

Выготский Л. С. Развитие высших психических функций. Собрание сочинений: в 6-ти т. Т. 3. Проблемы развития психики / под ред. А. М. Матюшкина. Москва : Педагогика, 1983. 368 с.

Доблаев Л. П. К вопросу о формировании профессионального психологического мышления у студентов. Форлирование основ профессионального ластерства в высшей школе. Ленинград : ЛГУ, 1973. C. $10-11$.

Емельянов Ю. Н. Активное социально-психологическое обучение. Ленинград : ЛГУ, 1985. 165 с.

Зинченко А. П. Организация рефлексии в процессах коллективного решения проблем. Рефлексия в науке и обучении: Тезисы докладов и сообщений. Новосибирск : НГУ, 1984. С. 204-206.

Калмыкова Е. С., Мергенталер Э. Нарратив в психотерапии: рассказы пациентов о личной истории (часть I). Психологический журнал. 1998. T. 19. № 5. С. 97-103.

Крупа В. В. Формування професійної готовності майбутніх фахівців 3 фізичної реабілітації до роботи в медичних закладах. Науковий вісник Чернівецького університету. Педагогіка та психологія: Зб. наукових праць. Чернівці, 2015. Вип. 747. С. 88-93.

Лактионов А. Н. Структурно-динамическая организация индивидуального опыта: дис. ... д-ра психол. наук: 19.00.01. Харьков, 2000. 451 c.

Леонтьев А. Н. Избранные психологические произведения: в 2-х т. / под ред. В. В. Давыдова и др. Москва : Педагогика, 1983. Т. 2. 318 с.

Михальчук Н. О., Хупавцева Н. О. Розвиток особистісного досвіду майбутнього психолога під час його професійної підготовки у вищій школі. Освіта регіону: політологія, психологія, колунікації. Український науковий журнал. Київ, 2011. № 3. С. 385-394.

Риклр П. Конфликт интерпретаций. Очерки о герменевтике / пер. с фр. и вступит. ст. И. Вдовиной. Москва : КАНОН-Пресс-Ц, 2002. $624 \mathrm{c}$.

(C) Prymachok Liudmyla

DOI (article): https://doi.org/10.32626/2227-6246.2020-47.179-205 
DOI: https://doi.org/10.32626/2227-6246.2020-47

Роджерс К. Взгляд на психотерапию. Становление человека / пер. с англ. М. М. Исениной; общ. ред. и предисл. Е. И. Исениной. Москва : Прогресс, 1996. 480 с.

Ролло М. Искусство психологического консультирования. Москва : Эксмо-Пресс, 2001. 384 с.

Рубинштейн С. Л. Очерки, воспоминания, материалы. Москва : Наука, 1989. $440 \mathrm{c.}$

Сохань Л. В., Тихонович В. А., Головаха Е. И. Разумная организация жизни личности: проблемы воспитания и саморегулирования. Киев : Наук. думка, 1989. 325 с.

Титаренко Т. М. Життєвий шлях. Основи психологї. Київ : Либідь, 1995. С. 307-330.

Юнг К. Психологические типы / пер. с нем. Минск : ООО «Попурри», 1998. 656 с.

Lewin, K. (1989). Field Theory and Experiment in Social Psychology: Concepts and Methods. American Journal of Sociology, 44, 868-896.

Rogers, C. R. (1983). Freedom to learn for the 80'S. Columbus etc. : Charles E. Merril Publ. Co. 312 p.

\section{References}

Ananiev, B. G. (2007). Izbrannyie psikhologicheskiie trudy [Selected psychological articles]. (Vols. 1-4). Sankt-Peterburg : Izd-vo SPbGU [in Russian].

Vashchenko, I. V., Onufriieva, L. A. (2018). Kontseptualni mezhi poniattia kopinh-stratehii osobystosti u psykholohii [Conceptual boundaries of the concept of coping strategies of personality in psychology]. S. D. Maksymenko, L. A. Onufriieva (Eds.). Problemy suchasnoi psykholohii - Problems of Modern Psychology: Collection of research papers of Kamianets-Podilskyi Ivan Ohiienko National University, G. S. Kostiuk Institute of Psychology at the National Academy of Educational Sciences of Ukraine, 41, 228-239. Kamianets-Podilskyi : Aksioma. DOI 10.32626/2227-6246.2018-41.228-239 [in Ukrainian].

Vygotskii, L. S. (1983). Problemy razvitiia psikhiki [Problems on mental development]. A. M. Matiushkin (Ed.). Razvitiie vysshikh psikhicheskikh funktsii - The development of higher mental functions. (Vol. 3). Moskva : Pedagogika [in Russian].

Doblaiev, L. P. (1973). K voprosu o formirovanii professionalnogo psikhologicheskogo myshleniia $u$ studentov [The question of the development of professional psychological thinking of students]. Formirovanie osnov professionalnogo masterstva v vysshei shkole [The de-

(C) Prymachok Liudmyla

DOI (article): https://doi.org/10.32626/2227-6246.2020-47.179-205 
DOI: https://doi.org/10.32626/2227-6246.2020-47 2020. ВИПУСК 47

velopment of the basics of professional excellence in the process of higher education]. Leningrad : LGU [in Russian].

Yemelianov, Yu. N. (1985). Aktivnoie sotsialno-psikhologicheskoie obucheniie [Active social and psychological training]. Leningrad : LGU [in Russian].

Zinchenko, A. P. (1984). Organizatsiia refleksii v protsessakh kollektivnogo resheniia problem [The organization of reflection in the processes of collective problem solving]. Refleksiia $v$ nauke $i$ obuchenii-Reflection in Science and Education: Proceedings of reports and talks, (pp. 204-206). Novosibirsk : NGU [in Russian].

Kalmykova, E. S., \& Mergentaler, E. (1998). Narrativ v psikhoterapii: rasskazy patsiientov o lichnoi istorii [Narrative in psychotherapy: stories of patients about their personal history]. Psikhologicheskii zhurnal - Psychological Journal, 5 (19), 97-103 [in Russian].

Krupa, V. V. (2015). Formuvannia profesiinoi hotovnosti maibutnikh fakhivtsiv $\mathrm{z}$ fizychnoi reabilitatsii do roboty $\mathrm{v}$ medychnykh zakladakh [The formation of professional readiness of future specialists in physical rehabilitation to work in medical institutions]. Naukovyi visnyk Chernivetskoho universytetu. Pedahohika ta psykholohiia Scientific Journal of Chernivtsi University, 747, 88-93. Chernivtsi [in Ukrainian].

Laktionov, A. N. (2000). Strukturno-dinamicheskaia organizatsiia individualnogo opyta [Structural and dynamic organization of individual experience]. Doctor's thesis. Kharkov [in Russian].

Leontiev, A. N. (1983). Izbrannyie psikhologicheskiie proizvedeniia [Selected psychological researches]. V. V. Davydov and others (Eds.). (Vol. 2). Moskva : Pedagogika [in Russian].

Mykhalchuk, N. O., \& Khupavtseva, N. O. (2011). Rozvytok osobystisnoho dosvidu maibutnoho psykholoha pid chas yoho profesiinoi pidhotovky $u$ vyshchii shkoli [The development of personal experience of a future psychologist during his / her professional training at higher school]. Osvita rehionu: politolohiia, psykholohiia, komunikatsii. Ukrainskyi naukovyi zhurnal - Education of the region: political sciences, psychology, communications. Ukrainian scientific journal, 3, 385-394. Kyiv [in Ukrainian].

Ricker, P. (2002). Konflikt interpretatsii. Ocherki o germenevtike [Conflict of interpretation. Essays on hermeneutics ]. I. Vdovina (Transl.). Moskva : KANON-Press-Ts [in Russian].

Rogers, C. (1996). Vzgliad na psikhoterapiiu. Stanovlenie cheloveka [A look at psychotherapy. The development of the person]. M. M. Isenina (Transl.). Moskva : Progress [in Russian].

Rollo, M. (2001). Iskusstvo psikhologicheskogo konsultirovaniia [The art of psychological counseling]. Moskva : Eksmo-Press [in Russian].

(C) Prymachok Liudmyla

DOI (article): https://doi.org/10.32626/2227-6246.2020-47.179-205 
DOI: https://doi.org/10.32626/2227-6246.2020-47

Rubinshtein, S. L. (1989). Ocherki, vospominaniia, materialy [Essays, memories, materials]. Moskva : Nauka [in Russian].

Sokhan, L. V., Tikhonovich, V. A., \& Golovakha, Ye. I. (1989). Razumnaia organizatsiia zhizni lichnosti: problemy vospitaniia i samoregulirovaniia [Reasonable organization of personal life: problems of education and self-regulation]. Kiev : Nauk. dumka [in Russian].

Tytarenko, T. M. (1995). Zhyttievyi shliakh [A way of life]. Osnovy psykholohii - Fundamentals of Psychology, (pp. 307-330). Kyiv : Lybid [in Ukrainian].

Jung, C. (1998). Psikhologicheskie tipy [Psychological types]. Minsk : OOO «Popurri» [in Russian].

Lewin, K. (1989). Field Theory and Experiment in Social Psychology: Concepts and Methods. American Journal of Sociology, 44, 868-896.

Rogers, C. R. (1983). Freedom to learn for the 80'S. Columbus etc. : Charles E. Merril Publ. Co.

Примачок Людмила. Парадигма професійного становлення фахівця 3 фізичної реабілітації з огляду на формування професійно значущого досвіду спеціаліста

\section{АНОТАЦІЯ}

Метою дослідження стали аналіз проблеми досвіду в психологічній царині, окреслення психологічних складових професійно значущого досвіду загалом і виокремлення компонентів професійно значущого досвіду фахівия з фізичної реабілітації, зважаючи на особливості професійної діяльності спеціаліста окресленої сфери діяльності.

Для розв'язання поставлених у роботі завдань використовувалися такі теоретичні методи дослідження: категоріальний, структурно-функціональний, аналіз, систематизація, моделювання, узагальнення.

Професійно значущий досвід матиме ціннісні, рефлексивні, комунікативні й операційні характеристики. Саме така сукупність параметрів досвіду забезпечує самостійність індивіда, його ціле-творчу або рефлексивну діяльність. Професійно значущий досвід також набувається у ситуаціях мимовільної активності, негайного (або інсайтного) реагування, автоматизмів, адаптивних або конструктивних дій тощо. При цьому наголошено, що і особистісно значущий, і професійно значущий досвід $\epsilon$ не лише науковою проблемою, але питанням життєтворення особистості, проблемою побудови свого власного образу світу. Професійно значущий досвід дає змогу суб'єктові змоделювати план виконання про(C) Prymachok Liudmyla

DOI (article): https://doi.org/10.32626/2227-6246.2020-47.179-205 
DOI: https://doi.org/10.32626/2227-6246.2020-47 2020. ВИПУСК 47

фесійної діяльності, презентувати маситаб життєвих уявлень, що дозволятиме особистості в кожний більш-менш важливий момент життєвого шляху усвідомити власне своє місце, побудувати біруркаційний простір особистісного та профресійного зростання тощо.

Активність індивіда, його позиція щодо професійно значущого соціуму виявляється не тільки і не стільки в тому, що він таким чином "робить внесок» у дещо спільне, інтегрально-соиіумне, а в тому, що він здатний без безпосереднього узгодження з усіма представниками соціуму створювати власну систему способів професійної взаємодії з людьми, своєрідний соціально-інтерпретаційний професійно спрямований комплекс. Зазначено, що такий підхід до проблеми професійно значущого досвіду є особливо важливим для галузі фізичної реабілітації, адже фрахівець має виявляти неабиякі вміння виконувати професійну діяльність у системі не абстрактної парадигми, а свого власного, набутого професійно значущого досвіду.

Висновки. Визначено, що до компонентів профресійно значущого досвіду фахівия з фізичної реабілітації відносяться: 1) ціннісний досвід; 2) досвід відрефрлексування власної професійної діяльності; 3) операціональний досвід. Зазначено, що ціннісний досвід виконує такі функції: розвивальну, диференційну, інтегративну, смислову, самовизначальну, функцію збереження. Функціями компонента «досвід відрефлексування власної профресійної діяльності» вважаються: суб'єктно актуалізована, профрілактична, інтерпретативна, адаптивна та функція коригування. До функцій операціонального досвіду належать: консультативна, пізнавальна, комунікативна, перцептивна, психотерапевтична, номінативна, функції цілевизначення та кодування тощо.

Ключові слова: професійно значущий досвід, чіннісний досвід, досвід відрефлексування власної професійної діяльності, операціональний досвід, функції профресійно значущого досвіду.

Примачок Людмила. Парадигма профессионального становления специалиста по физической реабилитации с учетом формирования профессионально значимого опыта специалиста

\section{АННОТАЦИЯ}

Целью исследования стали анализ проблемы опыта в психологической науке, определение психологических составляющих профессионально

(C) Prymachok Liudmyla

DOI (article): https://doi.org/10.32626/2227-6246.2020-47.179-205 
DOI: https://doi.org/10.32626/2227-6246.2020-47

значимого опыта в целом и выделение компонентов профессионально значимого опыта специалиста по физической реабилитации с учетом особенностей профессиональной деятельности специалиста данной сореры деятельности.

Для решения сформулированных в работе задач использовались следующие теоретические методы исследования: категориальный метод, метод структурно-фрунционального анализа, методы систематизации, моделирования и обобщения.

Профессионально значимый опыт включает ченностные, рефлексивные, коммуникативные и операциональные характеристики. Именно такая совокупность параметров опыта обеспечивает самостоятельность индивида, всю его творческую или рефлексивную деятельность. Профрессионально значимый опыт также приобретается в ситуациях непроизвольной активности, немедленного (или инсайтного) реагирования, автоматизмов, адаптивных или конструктивных действий. При этом отмечено, что и личностно значимый, и профессионально значимый опыт является не только научной проблемой, но и вопросом становления жизненного пространства личности, проблемой построения индивидом своего собственного образа мира. Профессионально значимый опыт позволяет субъекту смоделировать план выполнения профессиональной деятельности, представить маситаб жизненных представлений, что позволит личности в каждый более или менее важный момент жизненного пути осознать свое собственное место в мире, смоделировать бифуркационное пространство личностного и профессионального роста.

Активность индивида, его позиция по отношению к профессионально значимому социуму оказывается не только и не столько в том, что он таким образом "вносит вклад» в нечто общее, интегрально-социумное, a, прежде всего, в том, что индивид способен вне непосредственного согласования со всеми представителями социума создавать собственную систему способов профессионального взаимодействия с людьми, своего рода социально-интерпретационный профессионально направленный комплекс. В статье указано, что такой подход к проблеме профессионально значимого опыта особенно важен для отрасли физической реабилитации, ведь специалист должен проявлять незаурядные умения в выполнении профессиональной деятельности в системе не абстрактной парадигмы, а своего собственного, приобретенного профессионально значимого опыта.

(C) Prymachok Liudmyla

DOI (article): https://doi.org/10.32626/2227-6246.2020-47.179-205 
DOI: https://doi.org/10.32626/2227-6246.2020-47 2020. ВИПУСК 47

Выводы. Определено, что к компонентам профрессионально значимого опыта специалиста по физической реабилитации относятся: 1) ценностный опыт; 2) опыт отресрлексирования субъектом собственной профрессиональной деятельности; 3) операциональный опыт. Отмечено, что ценностный опыт выполняет следующие функции: развивающую, дифрференциальную, интегративную, смысловую, определяющую и функцию сохранения. Функциями компонента "опыт отрефлексирования субъектом собственной профессиональной деятельности» считаются: субъектно актуализированная, профилактическая, интерпретативная, адаптивная и функция коррекции. К функциям операционального опыта относятся: консультативная, познавательная, коммуникативная, перцептивная, психотерапевтическая, номинативная, функции целеполагания и кодирования.

Ключевые слова: профрессионально значимый опыт, ченностный опыт, опыт отрефлексирования субъектом собственной профессиональной деятельности, операциональный опыт, функции профессионально значимого опыта.

Original manuscript received December 18, 2019 Revised manuscript accepted January 05, 2020 